\title{
MEMBANGUN CROWDSOURCING DIET SEHAT MENGGUNAKAN METODE SCRUM (SISI PENYEDIA EXERCISE)
}

\author{
${ }^{1}$ Rizki Dwi Kurnia Dewi, ${ }^{2}$ Soni Fajar Surya Gumilang, ${ }^{3}$ Taufik Nur Adi \\ 1,2,3 Program Studi Sistem Informasi, Fakultas Rekayasa Industri, Telkom University \\ ${ }^{1}$ rizkidkd@students.telkomuniversity.ac.id, ${ }^{2}$ mustonie@telkomuniversity.ac.id, ${ }^{3}$ taufikna@telkomuniversity.ac.id
}

\begin{abstract}
Abstrak- Tubuh ideal merupakan impian setiap manusia. Seseorang dapat memperoleh tubuh ideal melalui diet sehat. Diet sehat merupakan kombinasi dua aktivitas yaitu mengatur pola makan dan exercise. Internet merupakan salah satu media yang dapat memberikan informasi tentang pengaturan pola makan dan aktivitas exercise untuk mendukung program diet. Pengguna menggunakan situs website untuk melakukan pencarian informasi. Di lain sisi, juga dibutuhkan suatu wadah bagi penyedia jasa exercise untuk memberikan informasi terkait excercise dan memberikan tawaran produk kesehatan maupun paket exercise. Oleh karena itu, diperlukan suatu pusat informasi untuk menampung informasi tersebut. Pusat informasi ini nantinya menerapkan model crowdsourcing. Aplikasi diet sehat dengan model crowdsourcing merupakan aplikasi untuk memberi informasi bagi pengguna dalam mendapatkan tubuh ideal dengan perhitungan sesuai inputan data pengguna, dan akan disarankan untuk mengkonsumsi makanan dan melakukan olahraga sesuai dengan hasil perhitungan. Sedangkan dari sisi penyedia jasa exercise berguna untuk memperluas jangkauan pasar serta mendapatkan keuntungan dari hasil pemesanan produk kesehatan maupun paket exercise oleh customer. Aplikasi ini dibangun menggunakan teknologi HTML, bahasa pemrograman PHP, database MySQL dan metode scrum. Metode scrum memiliki beberapa kelebihan yaitu lebih menghemat biaya dan waktu, dalam setiap sprint terdapat testing, saran yang berkelanjutan, adanya pertemuan setiap hari dan terdapat beberapa sprint.
\end{abstract}

Kata kunci: diet sehat, crowdsourcing, penyedia jasa exercise, scrum.

\section{PENDAHULUAN}

Memiliki tubuh ideal merupakan keinginan setiap manusia. Dengan tubuh ideal dapat memberikan banyak manfaat, seperti rasa percaya diri menjadi lebih meningkat dan yang lebih utama lagi yaitu terhindar dari beberapa penyakit. Salah satu cara untuk memiliki tubuh ideal yaitu dengan cara melaksanakan pengaturan pola makan (diet) dan madukannya dengan exercise. Rata-rata konsumsi kalori (kkal) per kapita sehari pada jenis makanan minyak dan lemak sebesar 231,08 kkal [1]. Berbanding terbalik dengan makanan sehat seperti sayur-sayuran, buah-buahan, daging, kacang-kacangan yang kurang dari $100 \mathrm{kkal}$. Sedangkan rata-rata aktivitas fisik yang dilakukan penduduk Indonesia masih tergolong rendah yaitu hanya mencapai 26,1 persen [2].
Data tersebut menyimpulkan bahwa kecenderungan masyarakat Indonesia mulai mengarah kepada gaya hidup tidak sehat. Hal tersebut bisa dipicu oleh kurangnya kesadaran akan pentingnya tubuh ideal serta kurangnya informasi mengenai jumlah kalori yang seharusnya dibakar setiap hari sesuai dengan kebutuhan kalori tubuh. Peneliti melakukan survey kepada 30 orang yang pernah melakukan diet dan pencarian diet secara acak. Pada Gambar 1 menunjukkan beberapa faktor yang menjadi kendala dalam melakukan exercise.

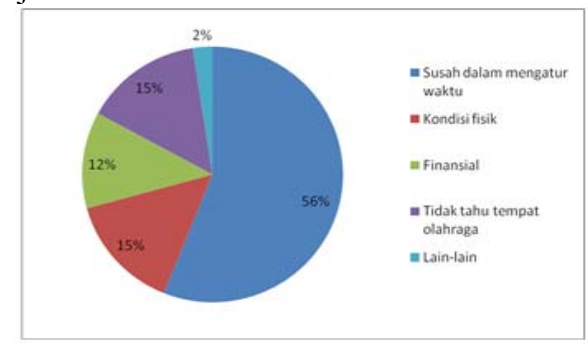

Gambar 1 Kendala melakukan exercise

Kendala dalam melakukan exercise yaitu kesulitan mengatur waktu, kondisi fisik, finansial, tidak mengetahui tempat olahraga dan faktor lainnya. Kendala tersebut dapat diatasi apabila terdapat suatu pusat informasi exercise, seperti informasi produk kesehatan, paket exercise, fasilitas-fasilitas exercise, tips-tips kesehatan dan lokasi dari penyedia jasa exercise. Di lain sisi, juga tidak terdapat suatu wadah yang digunakan oleh penyedia jasa exercise untuk memberikan informasi tersebut. Informasi tersebut dapat diberikan kepada customer dengan menggunakan internet.

Berdasarkan hasil wawancara kepada penyedia jasa exercise diperoleh bahwa penyedia jasa exercise membutuhkan website untuk melakukan promosi terhadap produk kesehatan maupun paket exercise, mengelola informasi, mengelola lokasi maupun mengelola hasil transaksi dari penjualan kepada customer. Beberapa alasan orang lebih memilih menggunakan aplikasi berbasis website berdasar hasil survey yaitu praktis, penyampaian lebih cepat karena bisa diakses dimana saja dan kapan saja, tidak perlu instalasi, mempunyai tampilan yang lebih user friendly dibanding mobile, dan dapat di akses melalui laptop, personal computer maupun mobile.

Oleh karena itu, diperlukan suatu pusat informasi untuk menampung informasi tersebut. Pusat informasi ini nantinya 
menerapkan model crowdsourcing. Faktanya beberapa website pada bidang diet dan olahraga belum menerapkan model ini dan tidak menyediakan tempat bagi penyedia jasa exercise sebagai pengisi konten informasi. Seperti www.diethuteri.com/kalkulator-kalori/,

www.doktersehat.com/kalkulator-kalori/, www.dietcerdas.com/bmr-calculator/ www.scientificpsychic.com/fitness/diet-kalkulator-id.html.

Model crowdsourcing memungkinkan penyedia jasa exercise saling berinteraksi dan berbagi informasi di satu tempat. Dengan adanya tempat untuk mempublikasi, hal ini akan memudahkan penyedia jasa exercise untuk memperluas jangkauan pasar serta mendapatkan keuntungan lebih dari hasil pemesanan produk kesehatan maupun paket exercise. Dalam pengembangan perangkat lunak dibutuhkan suatu metode. Salah satu dari metode pengembangan perangkat lunak yaitu scrum. Metode scrum memiliki beberapa kelebihan yaitu lebih menghemat biaya dan waktu, dalam setiap sprint terdapat testing, saran yang berkelanjutan, adanya pertemuan setiap hari dan terdapat beberapa sprint.

\section{METODE PENELITIAN}

\section{A. Model konseptual}

Model konseptual adalah konsep pemikiran yang membantu peneliti untuk merumuskan pemecahan masalah dan membantu dalam merumuskan solusi permasalahan yang ada. Model konseptual aplikasi website berbasis crowdsourcing untuk diet sehat pada sisi penyedia jasa exercise diawali input pada sistem yaitu berupa identitas penyedia jasa exercise. Dari hasil masukan tersebut akan dilanjutkan menuju proses yaitu registrasi. Proses tersebut mempunyai keluaran berupa akun penyedia jasa exercise. Setelah mendapatkan akun, maka penyedia jasa exercise dapat melakukan masukan lain seperti input produk kesehatan, paket exercise, fasilitas exercise dan artikel exercise. Dari masukan tersebut akan diproses dengan cara add, edit, view dan delete. Kemudian dari proses tersebut diperoleh keluaran berupa informasi, baik informasi produk kesehatan, paket exercise, fasilitas exercise dan artikel exercise.

Masukan yang berupa lokasi tempat exercise akan diproses ke dalam pemetaan lokasi tempat exercise, yang akan ditampilkan berupa peta lokasi tempat exercise. Pesanan yang telah dimasukkan oleh customer, yaitu pesanan produk kesehatan atau paket exercise, kemudian akan diproses dalam tiga tahap. Pertama konfirmasi kepada customer yang sebelumnya telah dicek terlebih dahulu oleh super admin dan dilanjutkan menampilkan pencatatan pesanan kepada penyedia jasa exercise. Pada tahap konfirmasi secara bersamaan terdapat proses update stok produk kesehatan ataupun paket exercise. Dari proses tersebut menghasilkan informasi berupa stok produk kesehatan ataupun paket exercise. Selain itu berupa status pembayaran kepada customer, dan detail pesanan.

Metode pembayaran yang telah dimasukan oleh super admin akan diproses yaitu berupa konfirmasi dan pencatatan traksaksi. Dari konfirmasi tersebut akan ditampilkan status pembayaran dan detail pembayaran atau transfer perbulan yang dilakukan oleh super admin kepada penyedia jasa exercise. Selanjutnya akan ditampilkan juga laporan transaksi.

\section{B. Metode Pengembangan}

Pada tahap pengembangan perangkat lunak, metode yang digunakan adalah metode scrum. Scrum adalah suatu kerangka kerja yang disusun untuk menunjang pengembangan produk yang kompleks [3]. Pada Gambar 2 dijelaskan mengenai proses dalam scrum.

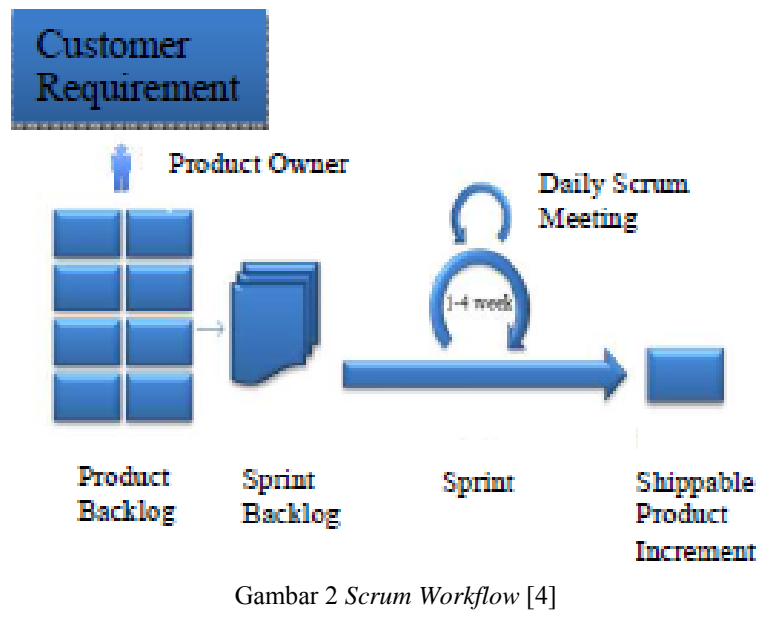

Pada metode scrum, user requirement ditentukan di awal dan dilakukan validasi sebelum masuk pada tahap selanjutnya sehingga pada tahap pengembangan hanya berfokus pada iterasi terus menerus. Iterasi tersebut dinamakan sprint. Setiap sprint memiliki beberapa fungsionalitas sesuai dengan yang telah ditentukan pada tahap perencanaan. Waktu pengerjaan setiap sprint adalah dua sampai empat minggu tetapi setiap harinya akan dilakukan daily scrum atau pertemuan untuk menilai kemajuan pekerjaan. Pada pengembangan aplikasi penelitian ini waktu satu sprint adalah dua minggu. Jika fitur yang diinginkan user telah divalidasi, maka selanjutnya adalah membuat roadmap. Roadmap ini bertujuan untuk membantu dalam membuat jadwal pengembangan perangkat dan lunak dan menentukkan target apa saja yang harus dicapai dalam waktu tertentu.

Apabila pendefinisan awal terhadap masalah dan ide yang sudah dikembangkan pada sprint tersebut dirasa cukup maka tahap selanjutnya yaitu merencanakan product backlog. Product backlog merupakan pendeskripsian produk yang akan dibuat. Product backlog akan dibagi menjadi beberapa sprint. Pada akhir setiap sprint akan dibuat small release dari fungsionalitas yang dibuat pada sprint tersebut untuk dievalusi dan disesuaikan dengan kebutuhan user. Siklus akan terus berulang sampai semua sprint pada product backlog selesai dilakukan. Fitur yang dihasilkan akan diminta feedback langsung dari user. Apabila ada kekurangan maka kembali lagi melakukan sprint backlog. 


\section{HASIL DAN PEMBAHASAN}

Website yang dikembangkan menggunakan model crowdsourcing. Crowdsourcing adalah tindakan yang dilakukan oleh suatu perusahaan atau lembaga yang mengambil tugas yang seharusnya dilakukan oleh karyawan perusahaan dan outsourcing, dengan disebarluaskan secara terbuka kepada banyak orang yang terkoneksi jaringan komputer, dalam hal ini adalah internet [5]. Pada model ini membantu bagaimana cara menarik minat user untuk berkunjung bahkan menjadi member dan memberikan informasi di dalam aplikasi ini. Pada Gambar 3 menjelaskan bahwa pada aplikasi ini menggunakan crowd sebagai pengisi konten aplikasi.

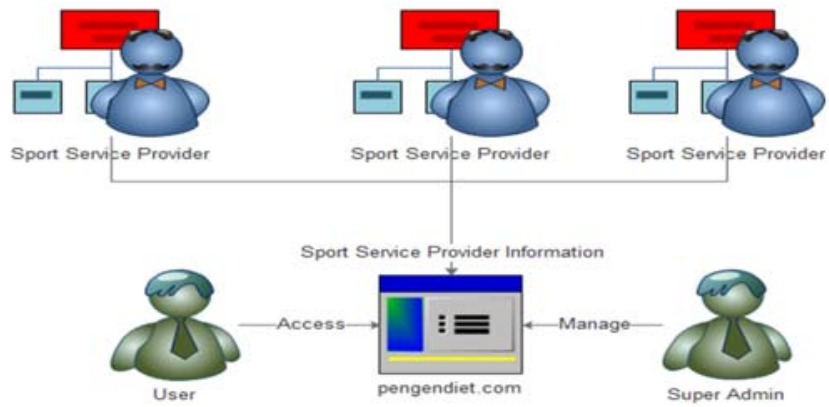

Gambar 3 Crowdsourcing diet sehat (sisi penyedia jasa exercise)

Penyedia jasa exercise merupakan user yang melakukan pengisian konten aplikasi dengan memberikan informasi terkait exercise. Reward untuk crowd itu sendiri adalah mendapatkan suatu reputasi tersendiri di dalam aplikasi. Semakin banyaknya konten yang ditulis dan semakin banyak review yang disukai oleh pengunjung lain maka semakin tinggi reputasinya.

\section{A. Analisis Spesifikasi Aktor}

Aktor dalam sistem Diet Sehat dari sisi penyedia jasa exercise dibagi menjadi dua bagian yaitu super admin dan penyedia jasa exercise. Super admin memiliki hak akses khusus terhadap sistem yaitu manage konfirmasi pembayaran customer, manage laporan keuangan \& konfirmasi pembayaran kepada penyedia jasa.

Penyedia jasa exercise merupakan user yang menyediakan dan mengelola informasi berupa paket exercise, produk kesehatan, fasilitas exercise dan artikel exercise. Penyedia jasa exercise juga dapat mengelola akun, mengelola konfirmasi pembayaran super admin, mengelola laporan keuangan transaksi, manage daftar pesanan, input question dan dapat melihat lokasi perusahaan.

\section{B. Business Model Canvass}

Business model canvas adalah sebuah model bisnis Gambaran logis mengenai bagaimana sebuah organisasi menciptakan, menghantarkan dan menangkap sebuah nilai [6]. Dengan adanya business model canvas akan membantu suatu organisasi dalam memetakan rancangan model bisnis. Bisnis model pada aplikasi penelitian sebagai berikut.

a. Key partners aplikasi diet sehat dari sisi penyedia jasa exercise ialah bank. Diet sehat bekerja sama dengan bank untuk pengelolaan keuangan dari hasil transaksi.

b. Key resource yang berpengaruh besar dalam aplikasi ini adalah web design, marketer, dan developer. Web design di sini berpengaruh besar terhadap interaksi user dengan aplikasi. Marketer ini berperan penting dalam mengenalkan aplikasi dan menawarkan aplikasi ini ke client. Developer berfungsi membuat aplikasi ini. Selain itu juga dibutuhkannya web online, hosting dan server untuk menunjang aplikasi ini, karena aplikasi ini berbasis web.

c. Key activities pada aplikasi ini merupakan pengisian informasi berupa produk, paket, fasilitas dan artikel yang berkaitan dengan exercise dan kesehatan. Selain itu juga kepada penjualan produk kesehatan dan paket exercise serta kegiatan promosi.

d. Value proposition yang diberikan oleh aplikasi ini terbagi yaitu, memberikan paket exercise kepada member sesuai dengan perhitungan diet yang telah dimasukkan oleh member dan dapat memberikan informasi kepada user terkait dengan kesehatan dan exercise.

e. Customer Relationship yang diterapkan disini adalah melalui pemberian informasi mengenai review keuangan dari hasil transaksi produk kesehatan dan paket exercise kepada penyedia jasa exercise. Sehingga perusahaan tidak perlu melakukan perhitungan manual. Selain itu juga terdapat informasi produk kesehatan dan paket exercise yang paling diminati user dari data hasil penjualan.

f. Channel yang digunakan yaitu internet dikarenakan aplikasi ini adalah sebuah aplikasi berbasis web.

g. Customer segments yaitu penyedia jasa exercise. Di sini lebih kepada persusahaan-perusahan yang menyediakan jasa exercise di wilayah Bandung dengan kategori yang dibatasi yaitu renang, aerobik, gym/fitness dan zumba. Penyedia jasa berfungsi untuk memberikan informasi kepada user mengenai exercise dan kesehatan

h. Cost structure merupakan biaya yang dikeluarkan dalam menjalankan bisnis dari aplikasi ini. Terdiri dari hosting, domain, server dan template. Biaya-biaya tersebut merupakan biaya operasional untuk mendukung pengembangan aplikasi.

i. Revenue Streams dalam aplikasi ini yaitu masih berasal dari bagi hasil antar penyedia jasa dan pemilik dari hasil penjualan, yaitu sebesar $10 \%$. Hasil dari pendapatan ini nantinya digunakan untuk membiayai pengembangan aplikasi. 
TABEL I

KEBUTUHAN FUNGSIONAL

\begin{tabular}{|c|c|c|c|}
\hline No. & Nama Kebutuhan & Deskripsi & Sumber (user) \\
\hline 1. & Manage akun & Proses untuk mengelola akun yang dilakukan oleh penyedia jasa exercise. & Penyedia jasa exercise \\
\hline 2. & Manage informasi & $\begin{array}{l}\text { Proses untuk mengelola informasi yang meliputi paket exercise, produk kesehatan, fasilitas } \\
\text { exercise dan artikel exercise, yang nantinya akan digunakan oleh member maupun guest. }\end{array}$ & Penyedia jasa exercise \\
\hline 3. & Input question & Proses untuk memberikan question terhadap super admin. & Penyedia jasa exercise \\
\hline 4. & $\begin{array}{l}\text { Manage konfirmasi super } \\
\text { admin }\end{array}$ & Proses untuk mengelola konfirmasi pembayaran yang telah dilakukan oleh super admin. & Penyedia jasa exercise \\
\hline 5. & $\begin{array}{l}\text { Manage laporan keuangan } \\
\text { transaksi }\end{array}$ & Proses untuk mengelola laporan keuangan transaksi yang masuk ke penyedia jasa exercise. & Penyedia jasa exercise \\
\hline 6. & Manage daftar pesanan & $\begin{array}{l}\text { Proses untuk mengelola daftar pesanan produk kesehatan dan paket exercise yaitu berupa } \\
\text { view dan update status penanganan bagi produk kesehatan. }\end{array}$ & Penyedia jasa exercise \\
\hline 7. & $\begin{array}{l}\text { Manage konfirmasi } \\
\text { pembayaran customer }\end{array}$ & $\begin{array}{l}\text { Proses untuk mengkonfirmasi pembayaran yang dilakukan oleh customer dan update status } \\
\text { menjadi confirmed yang secara bersamaan akan melakukan update stok produk kesehatan } \\
\text { dan paket exercise. }\end{array}$ & Super Admin \\
\hline 8. & Manage laporan keuangan & $\begin{array}{l}\text { Proses untuk mengelola laporan keuangan transaksi yang merupakan pendapatan bagi super } \\
\text { admin, menentukkan jumlah yang harus ditransfer kepada penyedia jasa. }\end{array}$ & Super Admin \\
\hline 9. & $\begin{array}{l}\text { Konfirmasi pembayaran } \\
\text { kepada penyedia jasa }\end{array}$ & Proses untuk konfirmasi pembayaran kepada penyedia jasa. & Super Admin \\
\hline 10. & Melihata lokasi perusahaan & Proses untuk melihat peta lokasi perusahaan. & Penyedia Jasa Exercise \\
\hline
\end{tabular}

C. Kebutuhan Fungsional

Pengendiet.com mempunyai beberapa fungsi berdasarkan aplikasi diet sehat dengan model crowdsourcing dari sisi penyedia jasa exercise. Tabel I menunjukkan kebutuhan fungsional dari aplikasi diet sehat.

Data Flow Diagram (DFD) atau dalam bahasa Indonesia menjadi Diagram Alir Data (DAD) adalah representasi grafik yang mengGambarkan aliran informasi dan transformasi informasi yang diaplikasikan sebagai data yang mengalir dari masukan (input) dan keluaran (output)
[7]. Data Flow Diagram (DFD) digunakan untuk merepresentasikan sebuah sistem atau perangkat lunak pada beberapa level abstraksi. DFD dapat dibagi menjadi beberapa level yang lebih detail untuk merepresentasikan aliran informasi atau fungsi yang lebih detail. Pada Gambar 5 merupakan DFD level 0 bagi penyedia jasa exercise. Sedangkan pada Gambar 6 merupakan DFD level 0 bagi super admin. DFD level 0 ini mengGambarkan fungsionalitas dari masing-masing aktor terhadap sistem crowdsourcing Diet Sehat dari sisi penyedia exercise.

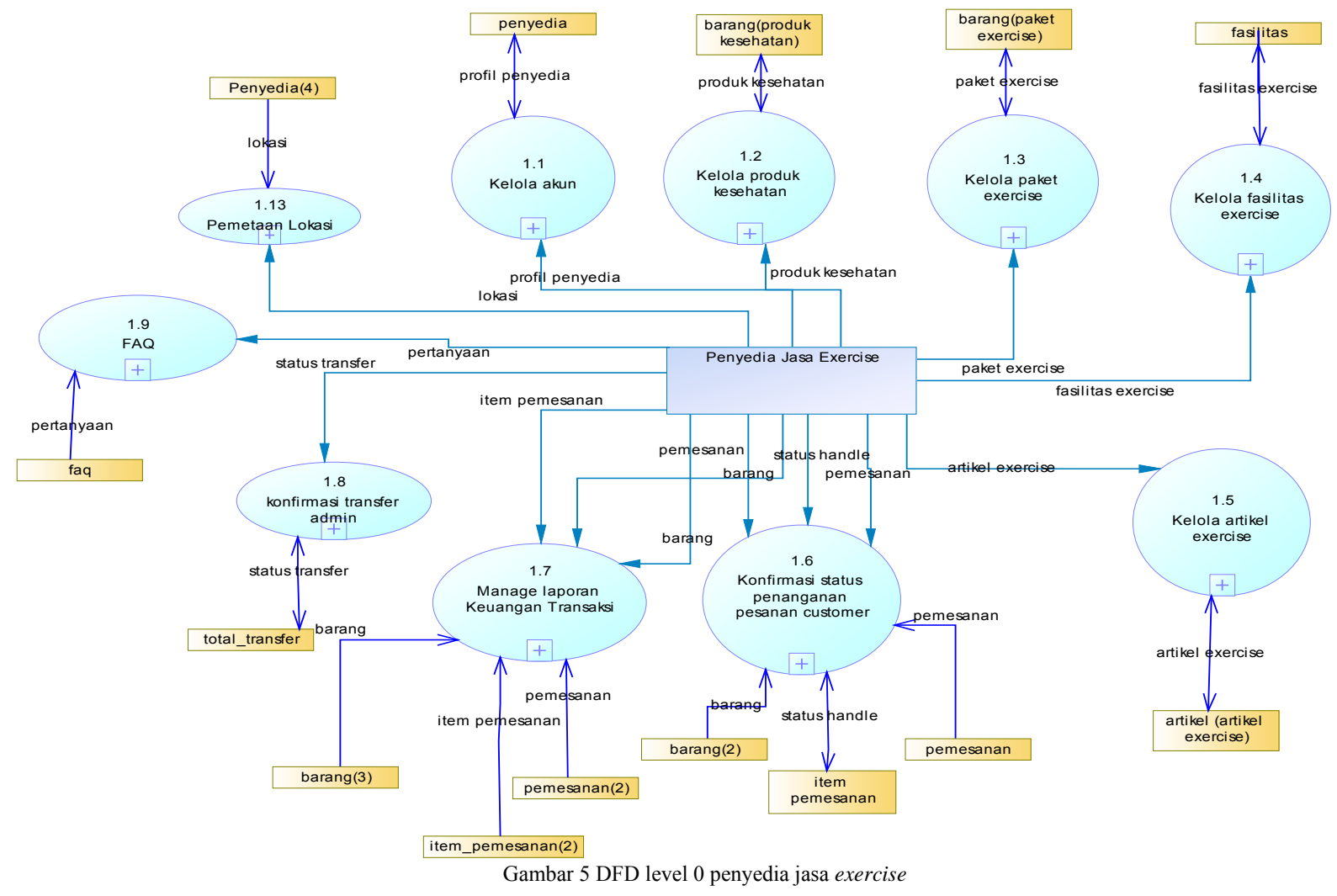




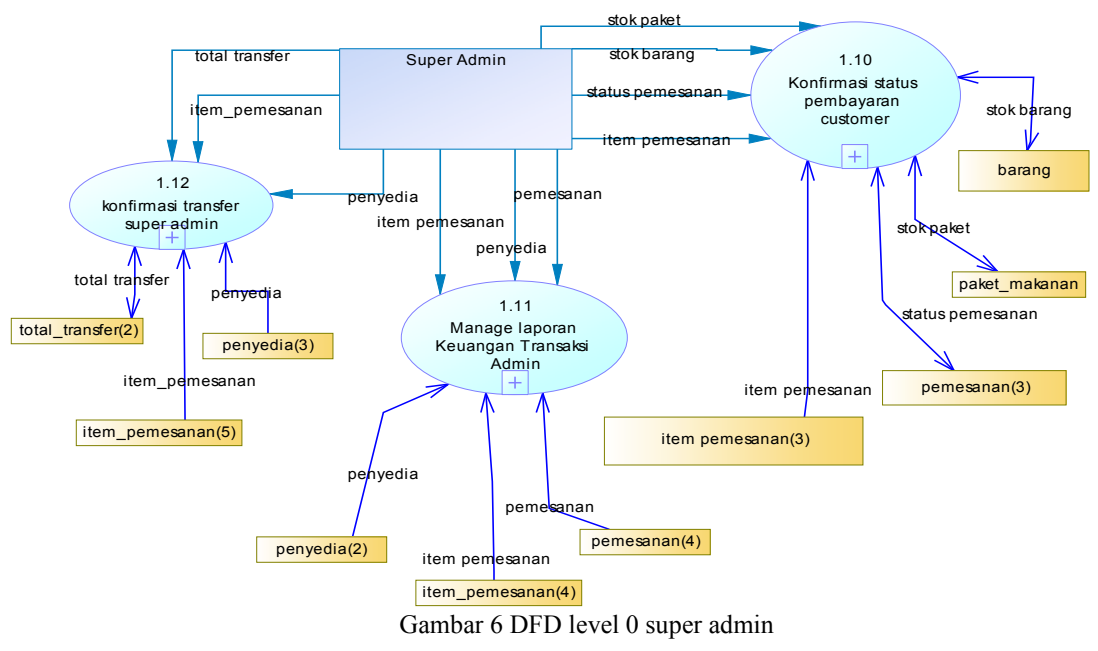

D. Entity Relationship Diagram

Perancangan database ini dimaksudkan sebagai acuan untuk melakukan proses coding. Di dalam entity relation diagram dapat dilihat bahwa suatu entitas

memiliki atribut apa saja di dalamnya dan juga hubungan antar entitas tersebut. Pada Gambar 7 merupakan entity relationship diagram yang telah dirancang.

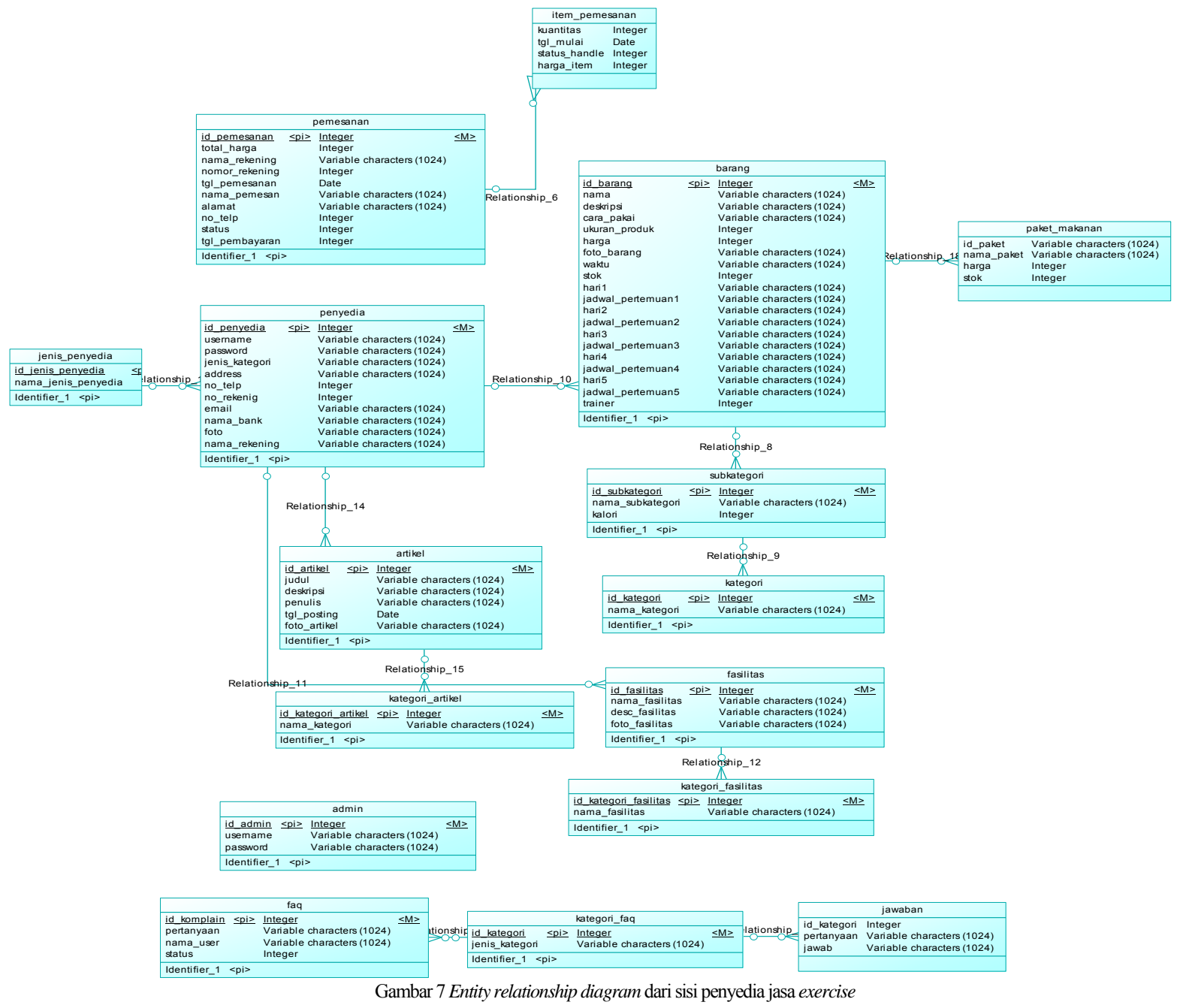




\section{E. Implementasi}

Untuk mengimplementasikan hasil aplikasi penelitian dibutuhkan web browser dan internet untuk mengakses data dari server database dan juga web server. Aplikasi Diet Sehat dengan nama domain Pengendiet.com dibangun menggunakan bahasa pemrograman PHP, database MySQL, dan Apache untuk web server. Website yang dibangun menggunakan desain template dari themeforest.com. Aplikasi ini telah diuji dibeberapa web browser, seperti Google Chrome versi 44.0.2398.0 dev-m, Mozilla Firefox versi 37.0.2 dan Internet Explorer versi 10. Hasilnya adalah fungsionalitas dari Pengendiet.com berfungsi dengan baik.

\section{F. Hasil Aplikasi}

Hasil akhir dari pembangunan aplikasi diet sehat berbasis website dengan model crowdsourcing dari sisi penyedia jasa exercise ini menghasilkan beberapa antar muka. Pada Gambar 8 merupakan halaman untuk melakukan posting informasi yang dilakukan oleh penyedia jasa exercise.
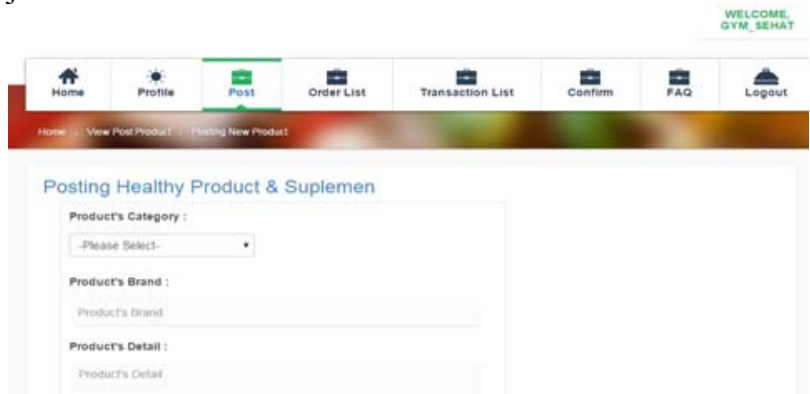

Gambar 8 Tampilan posting informasi penyedia jasa exercise

Pada Gambar 9 merupakan halaman untuk melihat pelaporan hasil keuangan transaksi.

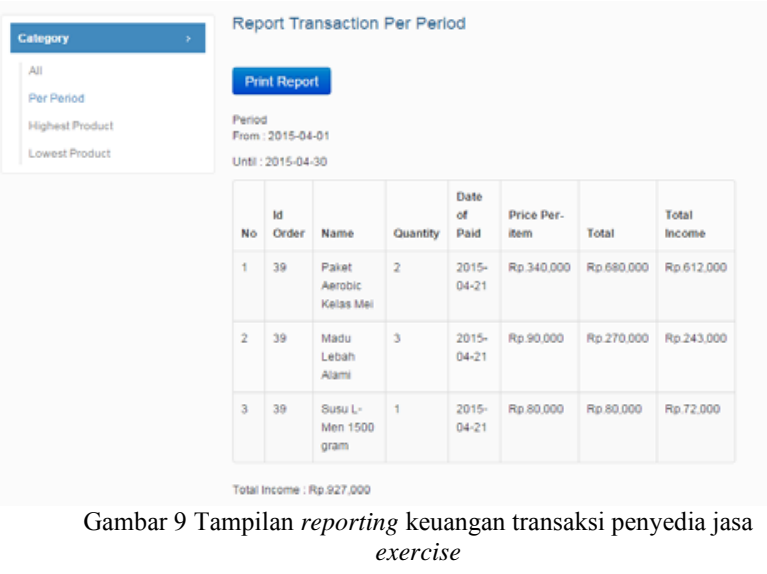

Pada Gambar 10 merupakan halaman untuk melakukan konfirmasi status pembayaran dari customer yang dilakukan oleh super admin.

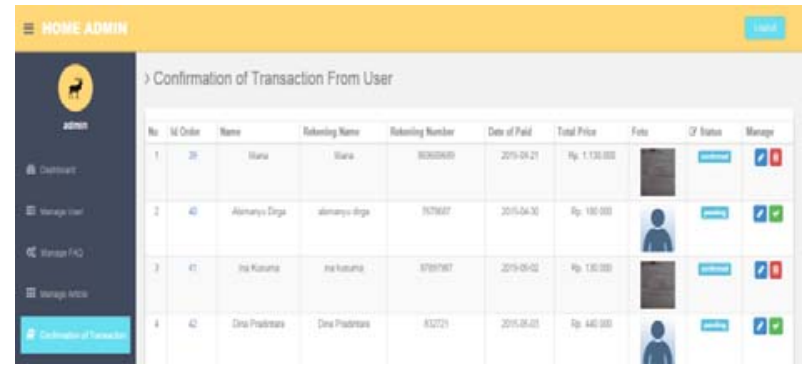

Gambar 10 Tampilan konfirmasi status pembayaran customer oleh super admin

G. Testing

Testing digunakan untuk mengecek fungsi aplikasi dapat berjalan sesuai dengan seharusnya atau terdapat bagian yang eror. Pengujian yang digunakan yaitu dengan pengujian fungsionalitas dan non-fungsionalitas. Pengujian fungsional termasuk ke dalam blackbox testing yang didasarkan pada spesifikasi software yang akan diuji [8]. Aplikasi ini diuji dengan memberikan masukan dan hasilnya diperiksa apakah sesuai dengan fungsi yang diharapkan.

Pengujian non-fungsional melibatkan pengujian perangkat lunak dari persyaratan non fungsional seperti kinerja, keamanan, user interface, dll [8]. Pengujian nonfungsional yang dilakukan adalah load testing. Pengujian ini adalah proses pengujian perilaku perangkat lunak dengan menerapkan beban maksimum dalam kemampuan akses dari perangkat lunak dengan memanipulasi data masukan yang besar [8]. Pengujian ini dilakukan untuk mengetahui informasi tentang ketersediaan server dan kinerja server yang akan digunakan untuk menyediakan layanan pada website Pengendiet.com. Pengujian ini dilakukan menggunakan Loader.io pada durasi satu menit. Hasil dari pengujian non-fungsinalitas ini dapat dilihat pada tabel II berikut.

TABEL II

HASIL PENGUJIAN KINERJA SERVER

\begin{tabular}{|c|c|c|c|c|}
\hline \multirow{2}{*}{$\begin{array}{c}\text { Throughput } \\
\text { (Request/menit) }\end{array}$} & \multicolumn{2}{|c|}{ Respon time (ms) } & \multirow{2}{*}{$\begin{array}{c}\text { Eror } \\
\text { Rate }\end{array}$} \\
\cline { 2 - 4 } & $\begin{array}{c}\text { Rata- } \\
\text { rata }\end{array}$ & Min & Max & \\
\hline 500 & 335 & 268 & 1094 & $0 \%$ \\
\hline 1000 & 346 & 273 & 5130 & $0 \%$ \\
\hline 2000 & 383 & 274 & 4979 & $0 \%$ \\
\hline 3000 & 435 & 266 & 8127 & $0 \%$ \\
\hline 4000 & 592 & 266 & 7869 & $7.2 \%$ \\
\hline 5000 & 440 & 267 & 6089 & $31.6 \%$ \\
\hline
\end{tabular}

Dari hasil diatas kita bisa menyimpulkan bahwa request per detik yang bisa ditangani server mendekati 4000 . Apabila melebihi request tersebut maka beberapa request akan timeout. Kesalahan ini terjadi apabila server tidak bisa memproses request pada waktu yang ditentukan, jadi request tidak gagal, hanya diproses sedikit lebih lama dari biasanya. Gambar 11 menunjukkan waktu penanganan terhadap request per menit. 


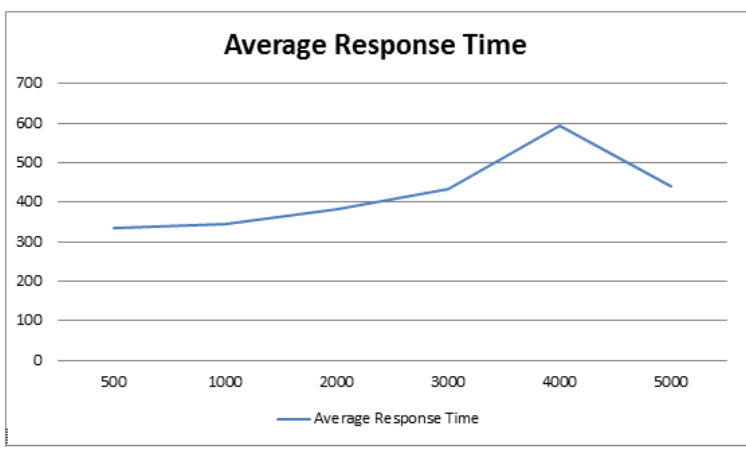

Gambar 11 Grafik waktu penanganan terhadap throughput

Hasil dari pengujian fungsionalitas Pengendiet.com dari sisi penyedia jasa exercise yaitu ditunjukkan pada Tabel III dan Tabel IV berikut. Dari hasil pengujian tersebut dapat disimpulkan bahwa aplikasi Diet Sehat fungsionalitasnya dapat berjalan dengan baik

TABEL III HASIL PENGUJIAN DARI PENGENDIET COM (SISI PENYEDIA JASA EXERCISE)

\begin{tabular}{|c|c|c|c|}
\hline No. & Test & Hasil Yang Diharapkan & Hasil \\
\hline 1. & $\begin{array}{l}\text { Registrasi sebagai } \\
\text { penyedia jasa } \\
\text { exercise. }\end{array}$ & $\begin{array}{l}\text { Terdapat notifikasi apabila } \\
\text { terdapat pengisian data yang tidak } \\
\text { sesuai dan diarahkan ke halaman } \\
\text { sign in apabila berhasil. }\end{array}$ & Passed \\
\hline 2. & $\begin{array}{l}\text { Sign in penyedia } \\
\text { jasa exercise. }\end{array}$ & $\begin{array}{l}\text { Terdapat notifikasi apabila } \\
\text { terdapat eror dan apabila berhasil } \\
\text { masuk halaman home. }\end{array}$ & Passed \\
\hline 3. & $\begin{array}{l}\text { View profile, edit } \\
\text { profile dan edit } \\
\text { foto profile. }\end{array}$ & $\begin{array}{l}\text { Dapat menampilkan profile } \\
\text { penyedia, terdapat notifikasi dalam } \\
\text { edit profile dan edit foto profile. }\end{array}$ & Passed \\
\hline 4. & $\begin{array}{l}\text { Posting, edit, view } \\
\text { dan delete } \\
\text { informasi }\end{array}$ & $\begin{array}{l}\text { Terdapat notifikasi berhasil atau } \\
\text { tidak. }\end{array}$ & Passed \\
\hline 5 . & View order list & $\begin{array}{l}\text { Dapat menampilkan order list } \\
\text { produk kesehatan dan paket } \\
\text { exercise. }\end{array}$ & Passed \\
\hline 6. & $\begin{array}{l}\text { Merubah status } \\
\text { penanganan produk } \\
\text { kesehatan. }\end{array}$ & $\begin{array}{l}\text { Dapat mengubah status dari } \\
\text { penanganan produk kesehatan. }\end{array}$ & Passed \\
\hline 7. & $\begin{array}{l}\text { View dan print } \\
\text { laporan keuangan } \\
\text { transaksi. }\end{array}$ & $\begin{array}{l}\text { Dapat melihat dan print laporan } \\
\text { berdasar periode, produk dan paket } \\
\text { yang paling diminati dan yang } \\
\text { paling tidak diminati. }\end{array}$ & Passed \\
\hline 8. & $\begin{array}{l}\text { Konfirmasi status } \\
\text { pembayaran dari } \\
\text { super admin }\end{array}$ & $\begin{array}{l}\text { Dapat merubah status konfirmasi } \\
\text { pembayaran dari super admin. }\end{array}$ & Passed \\
\hline 9. & $\begin{array}{l}\text { Input question } \\
\text { kepada super } \\
\text { admin }\end{array}$ & $\begin{array}{l}\text { Dapat input question kepada super } \\
\text { admin dan terdapat notifikasi. }\end{array}$ & Passed \\
\hline
\end{tabular}

TABEL IV

HASIL PENGUJIAN DARI PENGENDIET.COM (SISI SUPER ADMIN)

\begin{tabular}{|l|l|l|c|}
\hline No. & Test & Hasil Yang Diharapkan & Hasil \\
\hline 1. & $\begin{array}{l}\text { Sign in sebagai super } \\
\text { admin }\end{array}$ & $\begin{array}{l}\text { Terdapat notifikasi apabila } \\
\text { terdapat eror dan apabila berhasil } \\
\text { masuk halaman dasboard admin. }\end{array}$ & Passed \\
\hline
\end{tabular}

\begin{tabular}{|l|l|l|l|}
\hline No. & Test & \multicolumn{1}{|c|}{ Hasil Yang Diharapkan } & Hasil \\
\hline 2. & $\begin{array}{l}\text { Konfirmasi status } \\
\text { pembayaran customer }\end{array}$ & $\begin{array}{l}\text { Dapat merubah status } \\
\text { pembayaran dan update stok } \\
\text { produk dan paket. }\end{array}$ & Passed \\
\hline 3. & $\begin{array}{l}\text { Konfirmasi pembayaran } \\
\text { kepada penyedia jasa }\end{array}$ & $\begin{array}{l}\text { Dapat input bukti pembayaran } \\
\text { kepada penyedia jasa. }\end{array}$ & Passed \\
\hline 4. & $\begin{array}{l}\text { Melihat laporan } \\
\text { pendapatan super admin }\end{array}$ & $\begin{array}{l}\text { Dapat menampilkan daftar } \\
\text { pendapatan super admin. }\end{array}$ & Passed \\
\hline
\end{tabular}

\section{KESIMPULAN}

Kesimpulan dari penelitian ini adalah aplikasi diet sehat berbasis website dengan model crowdsourcing dari sisi penyedia jasa exercise, dapat membantu penyedia dalam berbagi informasi mengenai tempat melakukan exercise, fasilitas exercise, paket-paket exercise, produk kesehatan, dan tips kesehatan. Selain itu dengan aplikasi penelitian ini dapat membantu penyedia jasa exercise dalam memperluas jangkauan pasar, mengelola transaksi produk kesehatan maupun paket exercise, serta pelaporan transaksi.

\section{DAFTAR PUSTAKA}

[1] http://www.bps.go.id/tab_sub/view.php?tabel=1\&dafta $\mathrm{r}=1 \&$ id_subyek $=05 \&$ notab $=5, \quad$ diakses November 2014.

[2] http://www.depkes.go.id/resources/download/general/ Hasil\%20Riskesdas\%202013.pdf, diakses November 2014].

[3] Risnawati, akbar, M., \& Fatmasari., Analisis dan Perancangan Perangkat Lunak Penjualan Menggunakan Metode SCRUM (Studi Kasus CV. Rizki Mandiri Tebat Jaya Belitang), 2014.

[4] Neelima, E., \& K. Saile, N. D. A Study On SCRUM Agile Methodology and Its Knowledge Management Process, 2013.

[5] Braham, D. C., Crowdsourcing as a Model for Problem Solving An Introduction and Cases, 2008, pp 76.

[6] Dewobroto, W. S., Penggunaan Business Model Canvas Sebagai Dasar untuk Menciptakan Alternatif Strategi Bisnis dan Kelayakan Usaha. Jurnal Teknik Industri, ISSN:1411-6340, 2012.

[7] Rifada, M. Z., Aplikasi Pengelolaan Honor Korespondensi Daerah Berbasis Web (Studi Kasus : PT. Surya Citra Televisi). Bandung: Universitas Telkom, 2014.

[8] Software Testing Software System Evaluation, Tutorials Point (I) Pvt. Ltd, 2014. 